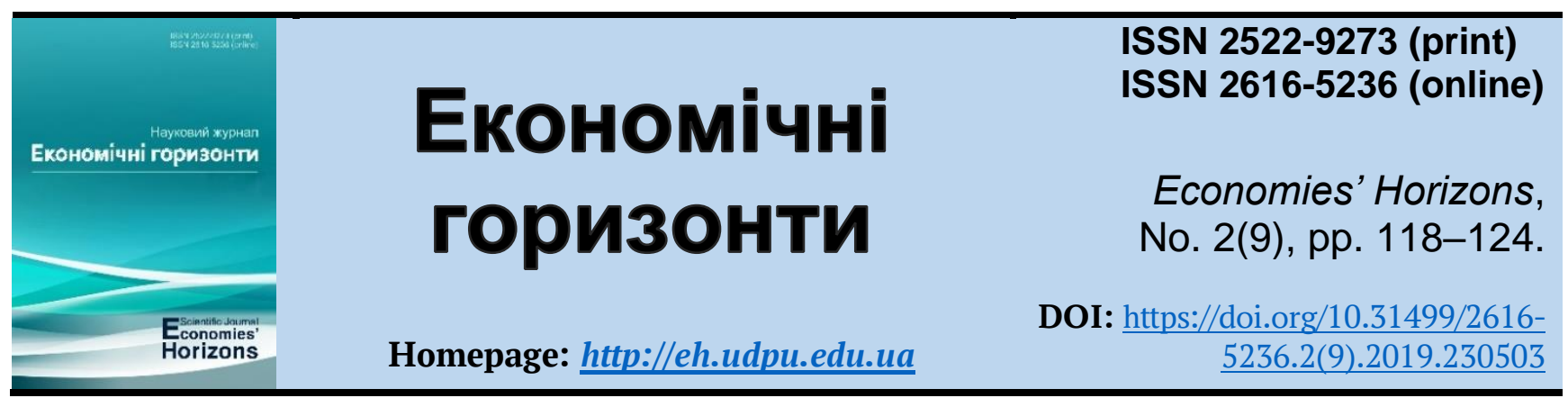

UDC 330.56:656.7

\title{
National features of business development in Ukraine: Global comparisons and spatial asymmetries
}

\author{
Iryna I. Nadtochii ${ }^{1}$, Cand. Ec. Sc., Associate Professor
}

Received: 8 May 2019

Accepted: 10 June 2019

\begin{abstract}
Nadtochii, I. I. (2019), "National features of business development in Ukraine: Global comparisons and spatial asymmetries", Economies' Horizons, no. 2(9), pp. 118-124, doi: https://doi.org/10.31499/2616-5236.2(9).2019.230503
\end{abstract}

Abstract. The research objective. The purpose of the article is to make a global comparison of national features of business development in Ukraine, taking into account the spatial asymmetry. Methodology. The theoretical and methodological basis of the study are the scientific works of scientists in the study of business process management in the system of competitive development of territories. To achieve this goal, the following research methods were used: theoretical generalization - generalization of the concept of globalization; methods of statistical analysis - for the analysis of indicators of the index of ease of doing business for Ukraine. Results. It is determined that globalization processes contribute to the formation of global trends in economic development of entrepreneurship in the system of competitive development of territories. The presence of the global economic space with its conjuncture and interconnections for underdeveloped territories can serve as an impetus for economic development through foreign investment, and may, conversely, increase the dependence of underdeveloped territories on developed countries by appropriating a share of additional product produced from underdeveloped resources. countries. During the period 2014-2019, Ukraine improved its position only in the ranking of the Ease of Doing Business Index, according to which in 2014 Ukraine ranked 116th, and in 2019 rose to 71 st place. In the ratings of competitiveness and prosperity, Ukraine's position has deteriorated somewhat. According to the competitiveness index, in 2014 Ukraine ranked 76th, and in 2019 it dropped to 85th place. According to the prosperity index, in 2014 Ukraine took 61st place, and in 2019 it dropped to 96th place. It has been studied that the index of ease of doing business is a signal to investors to choose a country to invest and do business. Investors are always interested not only in how easy it is to organize business, but also in how transparent the conditions of competition are and whether the interference of the state and government structures in the business process is excessive. The level of entrepreneurial activity is related to the level of corruption in the country: the lower the level of corruption, the higher the level of entrepreneurial activity. In addition, business development has a positive impact on living standards by creating jobs and providing income. Practical meaning. The results of the analysis will allow the authorities of the country and its individual territories to develop the necessary measures to improve business conditions, to improve living standards and to ensure the effectiveness of the economic development of the country or territory. Prospects for further research. Implementation of regional assessment of the business development trends.

Keywords: business process, globalization, spatial asymmetries, business, national features.

\footnotetext{
${ }^{1}$ Admiral Makarov National University of Shipbuilding, Kherson Branch; Associate Director for Education and Research; ORCID ID: https://orcid.org/0000-0003-0693-8000; e-mail: management@nuos.edu.ua.
} 
JEL Classification: M10; M13; R00; R58.

Number of references: 10; number of tables: 2; number of figures: $\mathbf{0}$; number of formulas: $\mathbf{0 .}$

\title{
Національні особливості розвитку бізнесу в Україні: глобальні порівняння та просторові асиметрії
}

\author{
Ірина Ігорівна Надточій ${ }^{1}$, к. е. н., доцент
}

Стаття надіŭшла: 08.05.2019 Стаття прийнята: 10.06.2019
Nadtochii I. I. National features of business development in Ukraine: Global comparisons and spatial asymmetries. Економічні горизонти. 2019. № 2(9), C. 118-124. DOI: 10.31499/2616-5236.2(9).2019.230503

Анотація. Мета дослідження. Метою статті є здійснення глобального порівняння національних особливостей розвитку бізнесу в Україні з урахуванням просторової асиметрії. Методологія. Теоретичною і методологічною основою дослідження є наукові праці вчених у дослідженні системи управління бізнес-процесів в системі забезпечення конкурентного розвитку територій. Для досягнення поставленої в роботі мети були використані такі методи дослідження: теоретичне узагальнення - узагальнення поняття глобалізація; методи статистичного аналізу - для аналізу індикаторів індексу легкості ведення бізнесу для України. Результати. Визначено, що глобалізаційні процеси сприяють формуванню загальносвітових тенденцій економічного розвитку підприємництва в системі забезпечення конкурентного розвитку територій. Наявність глобального економічного простору із своєю кон'юнктурою та взаємозв'язками для слаборозвинених територій може слугувати поштовхом до економічного розвитку за рахунок притоку іноземних інвестицій, а може, навпаки, посилити залежність слаборозвинених територій від розвинених країн за рахунок привласнення частки додаткового продукту виробленого із ресурсів слаборозвинених країн. За період 2014-2019 роки Україна покращила свої позиції тільки у рейтингу Індексу легкості ведення бізнесу, за яким у 2014 році Україна посідала 116 позицію, а у 2019 році піднялася на 71 місце. У рейтингах конкурентоспроможності та процвітання позиція України дещо погіршилася. За індексом конкурентоспроможності у 2014 році Україна займала 76 місце, а у 2019 році опустилася на 85 місце. За індексом процвітання у 2014 році Україна займала 61 місце, а у 2019 році опустилася на 96 місце. Досліджено, що індекс легкості ведення бізнесу виступає певним сигналом для інвесторів щодо вибору країни для вкладання коштів та ведення бізнесу. Інвесторів завжди цікавить не тільки наскільки просто можливо організувати ведення бізнесу, а і наскільки прозорими є умови конкуренції та чи не надмірним є втручання держави і владних структур у процеси ведення бізнесу. Рівень підприємницької активності пов'язаний із рівнем корупції в країні: чим нижче рівень корупції, тим вище рівень підприємницької активності. Крім того розвиток бізнесу позитивно впливає на рівень життя населення за рахунок створення робочих місць та забезпечення доходів населення. Практичне значення. Результати аналізу дозволять владним структурам країни та окремих їі територій розробити необхідні заходи для поліпшення умов ведення бізнесу, для покращення рівня життя населення та для забезпечення ефективності економічного розвитку країни чи території. Перспективи подальщих досліджень. Здійснення регіональної оцінки тенденцій розвитку бізнесу.

Ключові слова: бізнес-процес, глобалізація, просторові асиметрії, бізнес, національні особливості.

Кількість джерел: 10; кількість таблиць: 2; кількість рисунків: 0; кількість формул: 0.

\footnotetext{
${ }^{1}$ Національний університет кораблебудування імені адмірала Макарова, Херсонська філія; заступник директора з навчально-методичної та наукової роботи; ідентифікатор ORCID: https://orcid.org/00000003-0693-8000; e-mail:management@nuos.edu.ua.
} 


\section{Introduction.}

Business development is an important imperative for the competitiveness of national and regional economies. In today's crisis, businesses have to make every effort to survive. To improve the situation, it is important to develop mechanisms to stimulate the development of entrepreneurship, taking into account the new conditions of doing business in today's challenges, in particular - the pandemic. In addition, the tasks of increasing production volumes, increasing efficiency and productivity, using new technologies, updating material and technical equipment, etc. remain important.

\section{Literature review.}

Among modern economists, whose research is devoted to the problems of business process management in the system of competitive development of territories, it is necessary to note scientific works, in particular: S. Afontsev (2001); N. Khokhlov (2004); S. Ivanov (2005); R. Shchenin and S. Smirnov (2005), E. Khesin (2005); I. Kramarenko (2014); O. Chernova and K. Sushko (2017) and others. However, the complexity and versatility of this study requires a global comparison of national characteristics of business development in Ukraine, taking into account the spatial asymmetry.

\section{Methodology.}

The theoretical and methodological basis of the study are the scientific works of scientists in the study of business process management in the system of competitive development of territories. To achieve this goal, the following research methods were used: theoretical generalization - generalization of the concept of globalization; methods of statistical analysis - for the analysis of indicators of the index of ease of doing business for Ukraine.

\section{Research objectives.}

The purpose of the article is to make a global comparison of national features of business development in Ukraine, taking into account the spatial asymmetry.

\section{Results and discussions.}

Business is any business or business activity aimed at achieving the goal and solving problems. Business is understood as the implementation of any, even one-time agreements related to all types of economic activities that are aimed at generating income, profit. Thus, it is difficult to draw a clear line between business and entrepreneurship, but it is possible to note that business is a broader and at the same time accompanying concept to entrepreneurship. That is, any entrepreneurial activity is accompanied by business and business activity, which can be called business. Entrepreneurship can be considered as the basis of business.

Unfortunately, in Ukraine there is some negative experience in ensuring fair conditions for doing business. Previous experience in the development of entrepreneurship is evidence of the existence of significant obstacles in the form of corruption, unfair taxation and control, which significantly limited the freedom of entrepreneurial activity. Very often minor attempts at reform were declarative in nature and did not yield positive results. The situation with the development of entrepreneurship in Ukraine began to change for the better with the approval in 2015 of the Sustainable Development Strategy "Ukraine - 2020", which identified three main vectors of future movement: development; security; responsibility; pride (Sustainable Development Goals. Ukraine, 2017).

The vector of development provided for a number of structural reforms, which were to ensure macroeconomic stability in general and, in particular, favorable conditions for business and a transparent tax system. The security vector provided for the creation of security guarantees in general for the state and the national economy and for business in particular. The vector of responsibility also provided for the creation of guarantees, but these are already guaranteeing of access to education, health care and other services, and the responsibility was assigned to territorial communities. The vector of pride provided for the creation of conditions for mutual respect, tolerance and pride in one's own development. Current 
trends in business development in Ukraine are closely interrelated with the processes of globalization of economic activity.

Globalization can be considered as a stimulating factor of economic development in Ukraine. Globalization is the next stage or successor of internationalization, which in turn is a reflection of international cooperation of different countries, their regions and individual business structures. E. Khesin characterizes the end of the twentieth century with the beginning of a new stage of economic development - globalization, which is a logical continuation of internationalization (Khesin, 2005).

The processes of globalization significantly enhance economic cooperation between states on the basis of global capital formation, which partially weakens the economic sovereignty of individual countries and helps to eliminate economic borders (Khokhlov, 2004; Kramarenko, 2014). Globalization undermines the authority of the country's internal government, weakening its influence on economic processes and trade development. Management decision-making processes in the field of entrepreneurship and trade are focused on meeting corporate rather than public interests (Ivanov, 2005; Shchenin and Smirnov, 2005).

The globalization processes of business development are facilitated by the deepening of the international division of labor, the development of international logistics and digital technologies, and the development of transnational corporations.

A positive consequence or concomitant factor in the development of globalization are the manifestations of systematization of entrepreneurial activity in different countries of the world, which consist in the creation of new global forms of management. There is a need to create unified approaches to the conduct of economic activities by participants in the world economy focused on the common human interests, which in turn is a limiting factor for alternatives in the decision-making process of management decisions. Globalization processes contribute to the formation of global trends in economic development of entrepreneurship in the system of competitive development of territories. The presence of the global economic space with its conjuncture and interconnections for underdeveloped territories can serve as an impetus for economic development through foreign investment, and may, conversely, increase the dependence of underdeveloped territories on developed countries by appropriating a share of additional product produced from underdeveloped resources. countries. In addition, often the wealthy elites and businesses of underdeveloped countries do not want to invest their capital earned in international trade and cooperation in the development of their country, but exports them and invests in the economies of developed countries. Thus, in the processes of globalization there are both positive and negative consequences for the development of entrepreneurship in underdeveloped countries.

Thus, countries with underdeveloped businesses and economies are at risk of weakening or losing their resource base and capital. This threat arises due to the use of own resources in the production process and the appropriation of production results by investors and the reluctance of business representatives of underdeveloped countries to invest their earnings in the economy of their country and in the development of their territories.

In the context of globalization, developed countries have the advantage of five monopolies, which simultaneously weaken the economic situation and business development opportunities in underdeveloped countries.

Ukraine has made its choice to integrate into the world economic space and is forced to anticipate all negative manifestations and use the positive aspects of globalization phenomena and processes.

In the framework of the study of national features of the transformation of business processes in the system of competitive development of territories, it is considered appropriate to carry out: 1) monitoring the global 
dimension of national business development and competitiveness; 2) research of domestic characteristics of business development.

According to many scientists, the definition of global indices for Ukraine is very important primarily for Ukraine itself (Chernova and Sushko, 2017). Global development indices make it possible to compare different socio-economic spheres for different countries of the world, which provides an opportunity to justify management decisions on strategic guidelines and identify urgent priorities.

In the context of the study of national features of the transformation of business processes in the system of competitive development of territories, the following global indices are of interest: The Global Competitiveness Index (GCI); Ease of Doing Business Index (EDBI); the Legatum Prosperity Index (IP).

The Ease of Doing Business Index is also called "Doing Business" - "it is an integrated indicator, which is calculated based on the results of an annual survey that assesses the ease of doing business on ten indicators in 190 countries. The lower the figure, the higher the country's place in the ranking. The components of the Rating assess the regulations governing the activities of small and mediumsized enterprises throughout the life cycle, and their actual use in.

During the period 2014-2019, Ukraine improved its position only in the ranking of Ease of Doing Business Index, according to which in 2014 Ukraine ranked 116th, and in 2019 rose to 71 st place. In the ratings of competitiveness and prosperity, Ukraine's position has deteriorated somewhat. According to the competitiveness index, in 2014 Ukraine ranked 76th, and in 2019 it dropped to 85th place. According to the prosperity index in 2014, Ukraine ranked 61st, and in 2019 dropped to 96th place.

In the prosperity index, the growth of the business sub-index for the period 2014-2019 did not affect the growth of the overall value of the index due to the deteriorating situation with the development of economic and social spheres, government, education, security, personal freedom and environment.

The ranking of countries in the World Ease of Doing Business Index is determined on the basis of ten sub-indices. The best position is occupied by Ukraine in the sub-index "work with building permits" - 20th place, and the worst - in the sub-index "closure of the enterprise”, which corresponds to 146th place for Ukraine.

The numerical values of the components of the Ease of Doing Business Index indicate the need to simplify the conditions of the bankruptcy procedure of enterprises and the conditions of connection to the general power supply system.

The biggest positive movement was in the indicator "Protection of minority investors" - due to the disclosure of information about the final beneficiaries. The indicator "Work with building permits" also showed a significant increase - by eliminating the requirements for hiring an independent designer and technical engineer and introducing an online notification system.

The increase and decrease in the numerical values of the relevant components (sub-indices-indicators) of Ease of Doing Business Index for Ukraine reflect, respectively, the improvement or deterioration of the situation with various components of the business process (Table 1).

"The Global Favorable Business Conditions in Ukraine grew by $1.1 \%$ to $70.2 \%$. This means that Ukraine is currently $29.8 \%$ lower than the best practices established taking into account the results of all 190 countries participating in the Rating. The Ease of Doing Business Index serves as a signal to investors to choose a country to invest in and do business with. Investors are always interested not only in how easy it is to organize business, but also in how transparent the conditions of competition are and whether the interference of the state and government structures in the business process is excessive. 
Nadtochiy I. I. National features of business development in Ukraine: Global comparisons and spatial asymmetries

Table 1. Indicators of Ease of Doing Business Index (EDBI) for Ukraine

\begin{tabular}{|l|c|}
\hline \multicolumn{1}{|c|}{ Indicator } & 2019 indicator \\
\hline EDBI (DB) & 69.1 \\
\hline starting a business & 91.1 \\
\hline work with building permits & 77.2 \\
\hline receiving power supply & 59.2 \\
\hline property registration & 70.0 \\
\hline getting a loan & 75.0 \\
\hline protection of minority investors & 66.0 \\
\hline payment of taxes & 79.4 \\
\hline international trade & 77.6 \\
\hline ensuring the implementation of contracts & 63.6 \\
\hline termination of the enterprise & 31.7 \\
\hline
\end{tabular}

Source: Ministry for Development of Economy, Trade and Agriculture of Ukraine (2019); The World Bank (2019).

The level of entrepreneurial activity is related to the level of corruption in the country: the lower the level of corruption, the higher the level of entrepreneurial activity. In addition, business development has a positive impact on living standards by creating jobs and providing income.

On the other hand, the index of ease of doing business is a signal to the authorities of the country and its individual territories to develop the necessary measures to improve business conditions, improve living standards and ensure the effectiveness of economic development of the country or territory. Despite some positive dynamics in terms of doing business in Ukraine, in comparison with neighboring countries, Ukraine's position on the ILB rating remains the worst (Table 2). Ukraine lags behind Russia by 36 positions, and by Bulgaria - by 3 positions in the ranking of ease of doing business.

Table 2. Rating the Ease of Doing Business Index (EDBI) for Ukraine's neighbors

\begin{tabular}{|c|c|}
\hline Country & Rating Ease of Doing Business (EDBI) \\
\hline Poland & 40 \\
\hline Slovakia & 45 \\
\hline Moldova & 48 \\
\hline Belarus & 49 \\
\hline Hungary & 52 \\
\hline Romania & 55 \\
\hline Bulgaria & 61 \\
\hline Russia & 28 \\
\hline
\end{tabular}

Source: The World Bank (2019).

Comparing Ukraine's positions with neighboring countries in the ranking of ease of doing business suggests that there is an urgent need to develop conditions for doing business, as: introduction of a tax payment system and lending to support small and medium-sized businesses, introduction of bank start-up systems, improvement of connection conditions. power supply of such. Taking appropriate measures to improve the business environment will make it possible to withdraw from those significant amounts of financial resources.

\section{Conclusions.}

It is determined that globalization processes contribute to the formation of global trends in economic development of entrepreneurship in the system of competitive development of territories. The existence of the global 
economic space with its conjuncture and interconnections for underdeveloped territories can serve its own economic development through foreign investment, and, conversely, increase the dependence of underdeveloped territories on developed countries through the appropriation of private additional products from resources. countries. In addition, often the affluent elites and businesses of underdeveloped countries do not want to invest their capital in international trade and development workers, but to export them and invest in the economies of the world.

It has been studied that The Ease of Doing Business Index is a signal to investors to choose countries to invest in and do business. Investors are always interested not only in the possibility of simply organizing business, but in terms of transparency there are conditions of competition and not excessive interference of states and authorities in the business process. The level of entrepreneurial activity is filled with the level of corruption in countries: the lower the level of corruption, the higher the level of entrepreneurial activity. In addition, business development has a positive impact on living standards by creating jobs and providing income. On the other hand, the Ease of Doing Business Index is a signal to the authorities of countries and individual territories to develop the necessary measures to improve business conditions, increase living standards and ensure the efficiency of economic development of countries or territories.

\section{References}

Afontsev, S. (2001), “The problem of global management of the world economic system: theoretical aspects", World Economy and International Relations, no. 5, pp. 65-70.

Chernova, O. V. and Sushko, K. B. (2017), “The place of Ukraine in global economic ratings”, Economy and Society, vol. 9, pp. 110-114.

Ivanov, S. (2005), "Transnational corporations and small business in a globalized world", International Economics, vol. 4, pp. 96-101.

Khesin, E. (2005), "World Economy: entering the third millennium”, International Economics, vol. 3, pp. 5-19.

Khokhlov, N. (2004), "Globalization of the economy in the perspective of the evolution of property relations", Economy of Ukraine, no. 2, pp. 66-72.

Kramarenko, I. S. (2014), Reinzhynirynh navchalnoho protsesu: vid teorii do praktyky [Reengineering of the educational process: From theory to practice], FOP Shvets VD, Mykolaiv, Ukraine, 64 p.

Ministry for Development of Economy, Trade and Agriculture of Ukraine (2019), "Ukraine's place in the World Bank's ranking of “Doing Business”, available at: https://me.gov.ua/old/?lang=en-GB (Accessed 3 May 2019).

Shchenin, R. and Smirnov, S. (2005), "International integration associations in the regional spaces of the world", International economy, no. 5, pp. 22-33.

Sustainable Development Goals. Ukraine (2017), "Strategy of sustainable development of Ukraine until 2030", available at: http://www.ua.undp.org/content/dam/ukraine/docs/SDGreports/UNDP Strategy v06optimized.pdf (Accessed 3 May 2019).

The World Bank (2019), "Ease of Doing Business rankings", available at: https://www.doingbusiness.org/en/rankings (Accessed 3 May 2019).

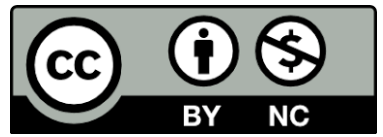

Цей твір ліцензовано на умовах Ліцензії Creative Commons «/з Зазначенням Авторства - Некомерційна 4.0 Міжнародна» (CC BY-NC 4.0). This is an open access journal and all published articles are licensed under a Creative Commons "Attribution-NonCommercial 4.0 International" (CC BY-NC 4.0). 